
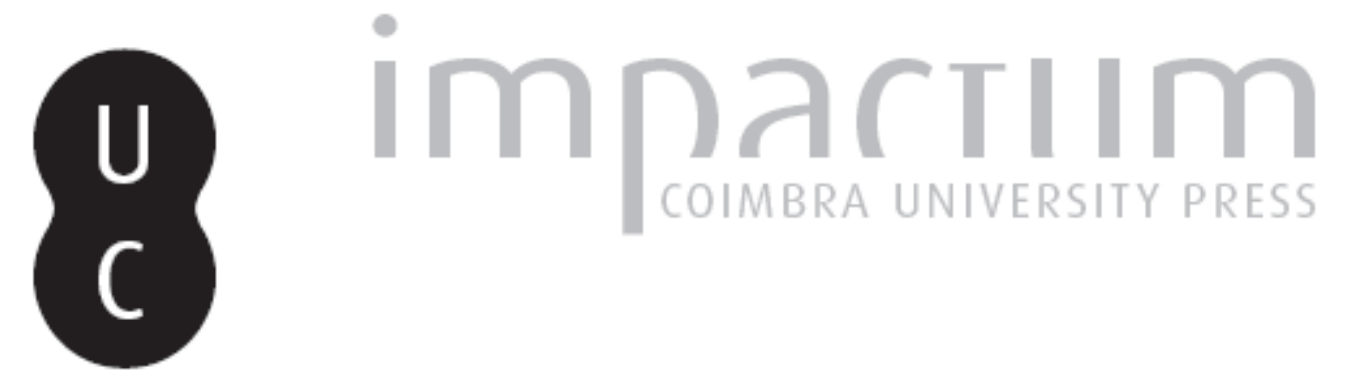

\title{
Lucernas da necrópole romana da Lage do Ouro (Crato)
}

\section{Autor(es): Caetano, José Carlos}

Publicado por: Faculdade de Letras da Universidade de Coimbra

URL persistente:

URI:http://hdl.handle.net/10316.2/37671

DOI:

DOI:http://dx.doi.org/10.14195/1647-8657_41_9

Accessed : $\quad$ 26-Apr-2023 07:25:08

A navegação consulta e descarregamento dos títulos inseridos nas Bibliotecas Digitais UC Digitalis, UC Pombalina e UC Impactum, pressupõem a aceitação plena e sem reservas dos Termos e Condições de Uso destas Bibliotecas Digitais, disponíveis em https://digitalis.uc.pt/pt-pt/termos.

Conforme exposto nos referidos Termos e Condições de Uso, o descarregamento de títulos de acesso restrito requer uma licença válida de autorização devendo o utilizador aceder ao(s) documento(s) a partir de um endereço de IP da instituição detentora da supramencionada licença.

Ao utilizador é apenas permitido o descarregamento para uso pessoal, pelo que o emprego do(s) título(s) descarregado(s) para outro fim, designadamente comercial, carece de autorização do respetivo autor ou editor da obra.

Na medida em que todas as obras da UC Digitalis se encontram protegidas pelo Código do Direito de Autor e Direitos Conexos e demais legislação aplicável, toda a cópia, parcial ou total, deste documento, nos casos em que é legalmente admitida, deverá conter ou fazer-se acompanhar por este aviso.

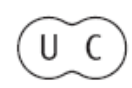




\section{CONIMBRIGA}

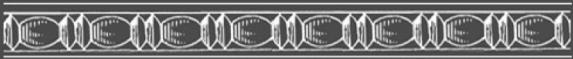

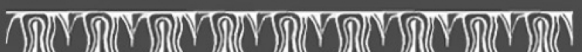
2

INSTITUTO DE ARQUEOLOGIA

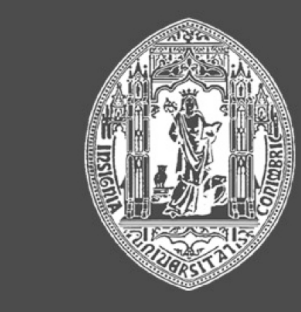

VOLUME XLI - 2002

F A C U L D A E D E LETRAS UNIVERSIDADE DE COIMBRA 
José CARLos CAETANo

Universidade de Évora

LUCERNAS DA NECRÓPOLE ROMANA DA LAGE DO OURO (CRATO) “Conimbriga" XLI (2002) p. 197-217

RESUMO: Dão-se a conhecer as lucernas encontradas na necrópole romana da Lage do Ouro. É uma pequena colecção apenas com nove exemplares dos sécs. III e IV.

São produto de olarias com difusão regional ou local e os moldes não eram originais; foram obtidos através do processo de remoldagem. Duas lucernas têm a marca GES.

RÉSUMÉ: On étudie les lampes provenantes de la nécropole romaine de Lage do Ouro (Crato). C'est une petite colléction de neuf exemplaires datés du III ${ }^{\text {ème }}$ e du IV ${ }^{\text {ème }}$ siècles ap. J. Ch.

Ce sont des produits des ateliers de la région; les moules n'étaient pas issus des prototypes massifes mais obtenus par la technique du surmoulage. Deux de ces lampes portent la marque GES. 
(Página deixada propositadamente em branco) 


\section{LUCERNAS DA NECRÓPOLE ROMANA DA LAGE DO OURO* (CRATO)}

\section{Introdução}

A necrópole romana da Lage de Ouro situa-se na freguesia de Aldeia da Mata, concelho do Crato. É uma necrópole rural, de uma villa cujos vestígios se encontram a poucas centenas de metros.

Foram escavadas 135 sepulturas, 45 de incineração e 90 de inumação; não sendo a totalidade dos enterramentos existentes, constituem, contudo, uma boa amostra para o estudo da evolução da necrópole.

Localiza-se numa pequena colina de pendor suave. No cume estão as incinerações e as inumações mais antigas; os restantes enterramentos estendem-se pelas encostas para leste, oeste e, em maior número, para sul. A expansão da necrópole não foi linear; notou-se um padrão em que, a partir do cimo da colina, os novos enterramentos envolviam os já existentes, formando um conjunto de "anéis" concêntricos, com os mais antigos no centro e os mais recentes na periferia.

Este aumento sucessivo do espaço ocupado corresponde a diferenças na cronologia das sepulturas, como se referiu, na sua orientação e na quantidade e qualidade das oferendas fúnebres depositadas em cada túmulo.

Entre os enterramentos do cume, bastante destruídos ${ }^{1}$ e com raros elementos cronológicos precisos, mas datáveis das últimas décadas do

* Este estudo tem por base um trabalho apresentado ao Seminário de Cerâmica Romana do Mestrado em Arqueologia da Feculdade de Letras da Universidade de Coimbra, da responsabilidade do Prof. Doutor Jorge de Alarcão, a quem agradeço as observações feitas. Os desenhos são do Dr. José Luís Madeira e as fotografias do Sr. Manuel Matias, a quem agradeço.

1 Devido à natural lixiviação do terreno, a espessura da camada de terra que os cobria era bastante reduzida; ficaram, por isso, mais expostos aos efeitos das diversas lavras mecânicas que o terreno sofreu. 
séc. I d.C. e 1. ${ }^{\text {a }}$ metade do séc. II d.C., e os túmulos mais periféricos, seguramente de tempos pós-romanos, nota-se uma transição gradual.

As fossas tumulares mais antigas estão orientadas N/S, mas à medida que se afastam do centro, passam a estar orientadas NNW/SSE ou NE/SW e finalmente E/W.

Ao mesmo tempo, o número de objectos que acompanhavam o defunto diminui de mais de uma dezena, nalguns casos, para cinco ou seis, depois para três, depois para um, quase sempre uma bilha, até se chegar às sepulturas mais periféricas em que não foi encontrado nenhum.

As oferendas fúnebres são na sua maioria cerâmicas de mesa ou de cozinha de fabrico comum. Quanto às cerâmicas ditas "finas", das mais antigas apenas se recolheram alguns fragmentos descontextualizados de Terra Sigillata Hispânica; começam a aparecer em força nos sécs. III e IV as taças e os pratos em Terra Sigillata Hispânica Tardia e Terra Sigillata Clara D, mas em quantidades percentualmente baixas.

As lucernas encontradas e os vidros, quer os provenientes da escavação, muito fragmentados e de difícil classificação tipológica, quer outros encontrados inteiros mas descontextualizados (Simões 1985: 123-125) são também datados maioritariamente dessa altura.

Quase se poderá pensar que a villa teve o seu floruit nesses séculos, época também em que a arquitectura de alguns túmulos é mais elaborada, e de que são exemplo os três recintos funerários escavados. São de forma quadrangular e delimitados por pequenos muretes de pedra, havendo um túmulo no centro de cada um (Caetano 2002: 323).

Embora violadas ainda em tempos antigos, possivelmente pelas mesmas gentes enterradas na periferia da necrópole e que inumaram uma criança por cima dos destroços de uma das violações, estas sepulturas destacavam-se pelo cuidado posto na sua construção.

Tinham o fundo revestido com grandes lateres, nas paredes de tijoleira havia nichos para a colocação do espólio fúnebre e estavam tapadas com grandes lajes de granito onde foram abertos orifícios para as libações.

A arquitectura das restantes sepulturas é diversificada, não tanto na sua forma mas mais nas coberturas, revestimentos e disposição interior dos diversos elementos. A exemplo de outros locais, nas incinerações terá havido uma preferência por covas circulares, ovaladas ou quadrangulares e nas inumações por fossas rectangulares (Fabião et al. 1998: 202). 
No entanto, enquanto em várias zonas do País se utilizaram maciçamente cerâmicas de construção e lajes nestas últimas estruturas funerárias, na Lage do Ouro as inumações foram maioritariamente depositadas em fossas sem qualquer revestimento, apenas se usando lajes e cerâmicas de construção nas coberturas (Caetano 2002: 329).

Os cadáveres foram colocados dentro de caixões de madeira, como se depreende do aparecimento dos pregos cruzados e dobrados in situ, o que dispensava o revestimento das paredes e do fundo (Frade/Caetano $1985 ; 1991 ; 1993)$.

\section{As lucernas}

As lucernas que agora se estudam são provenientes de nove sepulturas de inumação. Duas são lucernas de canal e as restantes são lucernas normalmente denominadas de bico redondo. Este tipo é bastante problemático; menos estudadas que as de volutas, abarcam um amplo período de tempo e as cronologias não estão bem estabelecidas (Morillo Cerdán 1999: 107); além disso, existem bastantes formas e variantes, algumas delas de produção regional ainda não devidamente individualizadas.

Neste conjunto das lucernas da Lage do Ouro surgiram dificuldades acrescidas. Em primeiro lugar, na sua maioria são produtos de remoldagens, cópias feitas por pequenas oficinas locais a partir de peças existentes no mercado. O processo de fabrico foi descuidado e mesmo as que são enquadráveis num tipo preciso não seguem os cânones "clássicos" desse tipo; pelas suas particularidades morfológicas mais parecem variantes ou sub-variantes.

As decorações são pouco nítidas, com o relevo mal conhecido, e nalguns exemplares foram retocadas e modificadas através de incisões feitas quando se retiraram do molde. Por outro lado, para algumas dessas decorações não foram encontrados paralelos.

As lucernas n. ${ }^{\text {os }} 1$ e 2 são do tipo Bailey P-I, lucernas de bico redondo separado do disco por um traço recto, sendo as peças mais antigas deste conjunto.

A n. ${ }^{\circ} 1$ é um exemplar de pequenas dimensões $(76 \mathrm{~mm}$ de comprimento) mas que foi utilizada, pois o engobe encontra-se enegrecido na zona do bico. Pela ausência de asa e dos pontos impressos que noutros exemplares marcam as extremidades do sulco, será uma das pri- 
meiras produções entre as lucernas com este bico, e está datado de meados do séc. I a meados do séc. II (Belchior 1969: 53; Morillo Cerdán 1990: 158).

Tem paralelo numa lucerna de Cosa, datada da 2. ${ }^{\text {a }}$ metade do séc. I (Fitch/Goldman 1994: 161, n. $\left.{ }^{\circ} 820\right)$. Há, no entanto, alguns aspectos a considerar. A superfície desta peça tem alguns grânulos de argila, cobertos pelo engobe, resultantes das bolhas de ar que não são absorvidas quando se utiliza gesso para fazer o molde a partir de um determinado modelo (Alarcão/Ponte 1976a: 98, n. ${ }^{\circ} 38$ e Bergès 1989: fig. 42, n. ${ }^{\text {os }}$ 248-251). Ora estes moldes de gesso eram os preferidos pelas pequenas oficinas, o que aliado à pouca nitidez das molduras poderá indicar ser um produto de remoldagem.

Nesse caso, há a considerar que estas produções de lucernas iguais mas em oficinas diferentes, porque resultam de cópias, podem não ser contemporâneas (Bonnet 1988: 19-20). Por isso, a cronologia desta peça poderá ser mais tardia que a tradicionalmente atribuída ao tipo.

A lucerna $n .^{\circ} 2$ foi classificada como sendo do mesmo tipo (Bailey P-I) não sem algumas reticências. Não tem asa e tem características morfológicas algo diferentes das que normalmente existem nas lucernas de bico redondo. A orla é estreita e arredondada e a separação entre o bico e o disco é feita, não por um traço recto que já existiria no molde, mas por dois traços entre os quais foi esgrafitada uma palma.

O perfil da peça também não se adequa ao tipo; se for comparado com as lucernas 29, de volutas, e 61, de bico cordiforme, de Conimbriga (Alarcão/Ponte 1976a: Pl. XXX), verifica-se que tem mais semelhanças com o primeiro do que com o segundo. Na orla, junto ao lado esquerdo do bico, há uma protuberância mal definida, como aliás toda a decoração, mas que poderá ser eventualmente o resíduo de um enrolamento de voluta que teria existido no modelo original.

O empastamento e a pouca nitidez da decoração e dos sulcos sugerem que o molde usado nesta peça teria sido feito a partir de uma outra igualmente pouco nítida, resultado de uma 3. ou 4. - remoldagem de uma lucerna mais antiga, possivelmente de volutas.

Quando tirada do molde, foi-lhe feita na base a marca esgrafitada GES sobre uma palma e, no bico, fizeram-se os sulcos que o separam do disco, numa tentativa de adaptação ao gosto da época e aos tipos em voga (o traço recto). Uma terceira palma foi também desenhada na parte inferior do bico. 
O empastamento dificultou também a identificação da figura representada no disco e para a qual não foram encontrados paralelos exactos. Poderá ser uma Minerva caminhando à direita, levando na mão direita a lança e na esquerda o escudo, no qual se nota estar pousado algo que poderá ser a coruja.

Tem algumas semelhanças com a Minerva da lucerna Q962 do British Museum, embora esta esteja virada à esquerda e com o braço que segura a lança dobrado. (Bailey 1980: 13).

A lucerna n. $^{\circ} 3$ é do tipo Bailey $\mathrm{O}$, com o bico limitado por um traço curvo, normalmente datadas da 2. ${ }^{a}$ metade do séc. I a inícios do III, sendo mais antigas as de orla lisa.

As estrias radiadas que decoram a orla têm uma cronologia mais tardia; em Cosa vão até ao séc. V (Fitch/Goldman 1994: 169), e em Conimbriga aparecem em exemplares datados de finais do séc. III, inícios do IV (Belchior 1969: 69, n. ${ }^{\circ}$ 172). Poderá ser esta a cronologia deste exemplar.

No disco está representado um busto de Hélios radiado segurando o chicote, também pouco nítido, e na base tem uma palma. A asa foi retocada, ostentanto uma palma incisa em vez dos habituais sulcos longitudinais.

Tem um paralelo quase exacto na lucerna 116 da colecção da Condessa de Lebrija, com a mesma marca mas a que falta o bico (Lopez Rodríguez 1981: 114-115, n. ${ }^{\circ} 116$ ), e numa outra do Museu de Torres Vedras, com a mesma decoração no disco e orla mas de tipo diferente (Bailey Q), datado do séc. III (Sepúlveda/Sousa 2000: 49-50).

As três lucernas seguintes classificam-se como Bailey Q, lucernas de bico cordiforme, embora de tipos diferentes. A lucerna $n .^{\circ} 4$ classifica-se como Bailey Q-IV, a n. ${ }^{\circ} 5$ como Bailey Q-VIII e a n. ${ }^{\circ} 6$ como Q-X.

Para Bailey, a distinção entre os tipos Q-IV a Q-X é meramente formal, sem qualquer significado cronológico, pois considera terem sido produzidos num período que engloba o último terço do séc. II e o 1. ${ }^{\circ}$ quartel do séc. III, podendo estender-se até meados deste século (Bailey 1980: 344-345). Essa distinção baseia-se essencialmente no tamanho das lucernas e na existência ou não de decoração na orla.

A n. ${ }^{\circ} 4$ enquadra-se tipo Bailey Q-IV, lucernas grandes com orla lisa; no entanto, a sua cronologia, tal como a dos n. ${ }^{\text {os }} 5$ e 6 , deverá ser distinta da atribuída às produções itálicas. Em Conimbriga apareceu um exemplar semelhante datado do séc. IV (Alarcão/Ponte 1976a: 99 e 101, n. ${ }^{\circ}$ 61); além disso, é um fabrico regional com a marca GES, que tem sido datado do séc. III (Cabral 1974-1977: 351). 
Tem também a asa decorada com uma palma incisa e no disco ostenta a representação mais clássica da Vitória alada, vista de frente sobre o globo segurando a coroa com a mão direita e a palma com a esquerda, que em outra ocasião foi definida como a variante a) das diferentes representações desta divindade em lucernas (Caetano 2001: 128-129).

Poderiam ser citados inúmeros paralelos para esta decoração do disco, talvez a mais utilizada e que aparece em lucernas de diversos tipos abarcando um amplo leque cronológico. No entanto, tal não se revela de grande utilidade, excepto quando são paralelos exactos, como a lucerna proveniente de uma sepultura de Tavira, que apenas difere na asas, com estrias longitudinais e na ausência de marca (Almeida 1953: 172-173, n. ${ }^{\circ} 151$, Est. XXXVI)

Há a salientar o tamanho da figura, que ultrapassa a superfície do disco. O globo, as extremidades das asas e a palma assentam sobre as molduras que o envolvem e a cabeça quase toca o início da asa da lucerna.

Não é muito comum encontrarem-se na Península Ibérica figurações com estas características; existem em três exemplares de Conimbriga (Belchior 1969: 63, n. ${ }^{\circ}$ 147, Est. XVIII, 4; Alarcão/Ponte 1976a: 106, n. ${ }^{\circ}$ 117, Pl. XXIX; Caetano 2001: 131-132, n. $\left.{ }^{\circ} 100\right)$.

São mais frequentes entre as produções itálicas, como as peças existentes no British Museum (Bailey 1980: 99 e 369, Q1397, Pl. 84), que tal como as de Conimbriga, certamente produtos itálicos, têm as orlas profusamente decoradas.

Esta gramática decorativa, cujo início se pode datar da 2. - metade do séc. II e se prolonga pelo séc. III, parece corresponder a uma inflexão na produção de lucernas, com a recuperação de motivos das lucernas de volutas e com uma cuidada execução dos motivos do disco, a que acresce a decoração das orlas (Caetano 2001: 131-132). A lucerna da Lage do Ouro tem a orla lisa, mas mostra que o oleiro, cuja marca GES está incisa na base, conhecia bem os modelos itálicos em voga.

A olaria que marcava os seus produtos com as iniciais GES terá sido um centro produtor com difusão regional. De acordo com os dados disponíveis, têm sido encontradas apenas na parte sul da Lusitânia: Mérida (Alvarez Sáens de Buruaga 1955-1957: 207-211), Villafranca de los Barros (Balil 1966: 121), Tróia (Costa 1973: 156-157, n. ${ }^{\circ} 105$, Est. XXXV), Barrosinha (Cabral 1973: 179, n. ${ }^{\circ}$ 5, Est. II, 5), Balsa ${ }^{2}$

2 Não foi referida em Nolen 1994; será que proveio de outro local que não Balsa? 
(Cabral 1978: 241, Est. I, 6), Alcácer do Sal (Cabral 1974-1977: 351, n. ${ }^{\circ}$, Est. II, 3), a que se juntam estas duas da Lage do Ouro.

As lucernas encontradas em território português são dos tipos Bailey P-I (a n. ${ }^{\circ} 2$ desta colecção) e Bailey Q (as restantes); nas encontradas em Espanha são desconhecidos, uma vez que as informações são escassas.

A marca é sempre semelhante, incisa e tendo na parte inferior uma palma, excepto nesta $n .^{\circ} 4$, só com as iniciais. O reportório iconográfico parece assentar na representação de divindades: Minerva e Vitória (Lage do Ouro), Mercúrio (Barrosinha), Hélios (Tróia) e Júpiter (Alcácer do Sal).

Desconhece-se a localização do centro produtor destas peças, embora tenha sido defendido que se situava em Mérida, ou nas suas proximidades (Balil 1966: 122).

Um aspecto a referir nestes dois exemplares da Lage do Ouro é a diferença de pastas; enquanto a do $n .^{\circ} 2$ é fina e depurada, de cor bege rosada, a do n. ${ }^{\circ} 4$ é mais grosseira e de cor alaranjada escura, semelhante à que se encontra em algumas tigelas e potes desta necrópole.

Esta diferença suscita várias questões, por enquanto sem resposta: utilização de barreiros próximos mas com características geológicas diferentes? Olarias do mesmo proprietário a laborar em locais distintos? Transferência do centro produtor de um sítio para outro?

A lucerna $n .^{\circ} 5$ inclui-se no Bailey Q-VIII, de médias dimensões e com a orla decorada. É uma peça algo assimétrica, com a asa e o bico deslocados para a esquerda em relação ao eixo da lucerna. Além disso, a largura da orla é variável, com um mínimo de $11 \mathrm{~mm}$ no lado direito e um máximo de $15 \mathrm{~mm}$ no esquerdo.

Esta particularidade pode dever-se uma deformação causada por qualquer pressão exercida quando a lucerna foi retirada do molde ou, o que será mais provável, à utilização de um molde composto por valvas obtidas por remoldagem a partir de lucernas com dimensões diferentes. Na moldagem da peça não houve o cuidado de escolher as valvas apropriadas, a da parte inferior era maior e houve a necessidade de as fazer coincidir, provocando a deformação e o aspecto assimétrico da peça.

A asa tem uma palma esgrafitada após a moldagem, e a orla está decorada com apenas uma fiada de pérolas grandes, que a ocupam na sua totalidade. $\mathrm{O}$ disco ostenta nove palmas dispostas radialmente a partir de uma moldura que ocupa o centro e rodeia o orifício de alimentação. 
É um conjunto decorativo bastante incomum, para o qual não foram encontrados paralelos exactos. As pérolas de grandes dimensões são frequentes em lucernas mais antigas, sendo uma das características do tipo Riotinto-Aljustrel (cfr. Luzón Nogué 1967; Alarcão/Alarcão 1966; Alarcão/Ponte 1976a). Duas lucernas de Cartago, de bico cordiforme, têm a orla decorada com uma fiada de pérolas; não são um paralelo exacto uma vez que cada uma dessas pérolas está rodeada de uma pequena moldura (Deneauve 1969: 204, Pl. XC, n. ${ }^{\text {os } 993-995) . ~}$

Quanto às palmas do disco, apenas se encontrou essa disposição radial em duas lucernas do British Museum, do tipo Q, em que as palmas, em número de seis, partem do orifício de alimentação, não existindo moldura (Bailey 1980: 88, n. ${ }^{\text {os }}$ Q 1335 e Q 1336).

$\mathrm{Na}$ base tem um círculo cavado, que poderá ser uma marca ou ter apenas um intuito decorativo. Com círculos semelhantes conhecem-se uma lucerna de Miróbriga, do séc. II (Almeida 1951: n. ${ }^{\circ} 3$ ) e outra de Tróia, já datada do séc. III (Costa 1973: 178, n. ${ }^{\circ}$ 144).

Estes círculos, que poderão funcionar como marca, não têm por si só qualquer significado cronológico, uma vez que aparecem em lucernas de tipos distintos e abrangendo um amplo período de tempo. Neste caso, a valva inferior foi obtida por remoldagem, pelo que será a marca da lucerna original e não desta.

A n. ${ }^{\circ} 6$ é mais recente, pertence ao tipo Bailey Q-X, e está datada da época dos Severos ou posterior (Bailey 1980: 375). No entanto, como todas as lucernas deste tipo, a sua cronologia poderá abranger o séc. IV. É uma lucerna com o disco liso e bastante côncavo e a orla decorada com cinco fiadas concêntricas de pequenas pérolas.

Tal como a $n .^{\circ}$, e pelas mesmas razões, também esta lucerna apresenta uma acentuada assimetria, com a asa e o bico deslocados para a direita e o disco para a esquerda; a largura da orla varia; à esquerda do bico tem $14 \mathrm{~mm}$, que é a largura de toda a faixa ocupada pelas pérolas, mas à direita da asa mede $21 \mathrm{~mm}$, havendo uma área não decorada.

A base tem uma palma incisa, com traços bem marcados e profundos; à sua esquerda vê-se o que parece ser a letra $\mathrm{C}$, também incisa, juntamente com outros traços bastante ténues que poderão eventualmente representar outras letras não identificáveis.

Numa primeira análise poderá parecer tratar-se de uma marca combinando um nome ou iniciais e a palma; no entanto, a diferença na profundidade dos traços de uns e outros não o confirma. Poder-se-ia pensar que as letras e a palma foram traçadas por mãos diferentes, mas, 
pelo que se sabe, cada lucerna seria trabalhada apenas por um operário, havendo mesmo sinais que se colocavam junto às marcas para distinguir cada produção individual (Bailey 1980: 103; Morillo Cerdán 1999: 278-279).

Será mais provável que o $\mathrm{C}$ e as restantes letras tenham constituído a marca da lucerna original de onde se moldou a valva inferior; ficando empastadas e mal conhecidas, não houve o cuidado de as apagar, esgrafitando-se por cima a marca do actual fabricante.

Tem um paralelo quase exacto numa lucerna da colecção da Condessa de Lebrija, também marcada com uma palma mas sem a assimetria que caracteriza esta (Lopez Rodrígues 1981: 117, n. ${ }^{\circ} 157$ ).

As palmas esgrafitadas, como as dos n. ${ }^{\text {os }} 3$ e 6 são frequentes, no Sul Peninsular, acompanhando marcas formadas por letras (GES, CË, $\ddot{E} V$, MV...) ou isoladas. Exceptuando a marca CË sobre palma de Conimbriga (Caetano 2001: 111-112), o local mais a norte onde apareceu uma palma, neste caso isolada, foi no mercado de Torres Vedras, numa lucerna Bailey P-I do séc. II (Sepulveda/Sousa 2000: 17, 34 e 44-45, n. ${ }^{\circ}$ 2).

Do mesmo tipo e data é uma lucerna de Tróia, também com uma palma isolada (Costa, 1973: 179-180, n. ${ }^{\circ}$ 148, Est. LXXV, 2); aparece ainda em algumas das chamadas lucernas Riotinto-Aljustrel em Balsa datadas de entre Cláudio e meados do séc. II (Nolen 1994: 42-43, lu-26, lu-28 e lu-29). Contudo, a palma isolada está maioritariamente associada a produções dos tipo Bailey $Q$ e $R$, dos sécs. III e IV. Sem pretensões de exaustividade e além das já citadas, apareceram ainda na Barrosinha (Cabral 1973: 177, n. ${ }^{\circ}$ 2, Est. I, 2), em Torre das Arcas (Alarcão/Ponte 1976b: 84, n. ${ }^{\circ} 22$, Est. III e VII) e em vários locais do Algarve (Almeida 1953: n. ${ }^{\text {os }} 114$ e 251).

As lucernas seguintes são imitações regionais das lucernas de canal tipo Bailey $\mathrm{N}$, não se integrando em nenhum dos subtipos definidos. As produções itálicas têm uma cronologia desde finais do séc. I a meados do séc. III (Bailey 1980: 228-290), mas continuam a ser produzidas no séc. IV, especialmente nas províncias setentrionais (Morillo Cerdán 1999: 128).

Nas produções mais tardias o ângulo entre o bico e o corpo da lucerna esbate-se, ganhando esta um aspecto mais piriforme (Belchior 1969: 70). As lucernas da Lage do Ouro contam-se entre essas produções mais tardias, e podem ser datadas do séc. IV, o que é confirmado pelo prato de Terra Sigillata Hispânica Tardia, datado de inícios do séc. IV a inícios do séc. V, encontrado na mesma sepultura da n. ${ }^{\circ} 7$ (Frade 1998: 9-10). 
Esta, embora com um aspecto rude e um fabrico descuidado e grosseiro, conserva as características do modelo, com o canal aberto, o bico comprido e, na orla, os resíduos das protuberâncias. A asa foi retocada após a moldagem, tendo sido decorada com uma palma esgrafitada.

A n. ${ }^{\circ} 8$ é uma lucerna pouco comum. Tem o canal aberto, o bico curto e asa, a que se acrescentaram decorações na orla e no disco para as quais não foram encontrados paralelos. Estes motivos, que existiriam no molde, foram também retocados após a moldagem.

A orla tem um padrão de palmas fazendo ziguezague; o disco ostenta um busto virado à esquerda e com o braço direito levantado por cima da cabeça e segurando o que parece ser um bastão. Poderá eventualmente ser Hércules segurando a maça e coberto pela pele do leão de Nemeia, cujas patas caem sobre o peito. Não foram encontrados paralelos para estas decorações do disco e orla. As palmas foram reavivadas após a moldagem e em toda a parte interna da moldura que separa o disco da orla e que se prolonga até ao bico há pequenos traços incisos.

$\mathrm{Na}$ base, inicialmente lisa, foram incisos dois sulcos concêntricos, formando uma moldura; no interior foram desenhados seis traços que se juntam perto do centro e entre os quais há pontos incisos. Não se encontrou qualquer paralelo para esta decoração ou marca; a pressão exercida durante a sua execução tornou a base bastante côncava.

No reservatório existem duas nervuras, uma de cada lado do bico. São semelhantes às nervuras das lucernas de volutas simples, o que faz pensar que na moldagem desta lucerna foram também utilizadas valvas provenientes de peças diferentes e que não coincidiam. Mais uma vez, isto também se comprova pela dimensão da orla, que varia entre $12 \mathrm{~mm}$ e $20 \mathrm{~mm}$.

A lucerna $n .^{\circ} 9$ está demasiado gasta para que se possa classificar com segurança. No entanto, poderá incluir-se no tipo Bailey R, lucernas sem separação entre o bico e o disco. Na orla há restos de uma decoração de estrias radiadas e no disco há alguns traços do que poderia ter sido uma concha.

De pequenas dimensões, tem um aspecto compacto e piriforme; parece ser um daqueles tipos tardios grosseiros, normalmente datados dos sécs. III e IV, como a lucerna 172 de Conimbriga (Belchior 1969: 69, n. $\left.{ }^{\circ} 172\right)$. 
A pasta é alaranjada, muito grosseira e com elementos não plásticos de grandes dimensões, em tudo semelhante à de algumas louças de cozinha exumadas nesta necrópole. Não é descabida a hipótese de ser originária de uma olaria onde a produção principal fosse a cerâmica comum, constituindo as lucernas apenas um fabrico residual para auto-abastecimento ou para um comércio estritamente local.

\section{Conclusões}

Estas lucernas constituem, como se viu, um conjunto com características próprias, algo diferentes do que se costuma encontrar em outras estações arqueológicas da mesma época. Mas para serem convenientemente valorizadas, terão que ser consideradas dentro do conjunto da necrópole e, consequentemente, relacionadas com a villa a que servia de cemitério.

Não cabe aqui a definição da estratificação social nem da evolução da villa com base nos espólios funerários; mas se forem consideradas as sigillatas como indício do poder aquisitivo dos seus habitantes, verifica-se que, aparte alguns diminutos fragmentos de Terra Sigillata Hispânica, somente no séc. III e em maior número no séc. IV começam a fazer parte das oferendas fúnebres taças e pratos de Terra Sigillata Hispânica Tardia e Terra Sigillata Clara C e D (Frade 1998).

Por outro lado, as sepulturas onde foram depositadas correspondem a cerca de 10/11\% da totalidade; a comparação com os $52 \%$ da necrópole de Santo André (Montargil) (Viegas/Nolen/Dias 1981: 46) é reveladora. Colocada de parte a comparação com as necrópoles da zona de Elvas, por não ter sido possível reconstituir a maior parte dos espólios (Nolen 1985), é no Monte do Farrobo (Aljustrel) que encontramos uma situação semelhante. Nesta necrópole apenas a sepultura 20 se destaca pelos seus materiais (Alarcão 1974).

Recorrendo aos critérios recentemente propostos para a distinção entre os diversos tipos de estabelecimentos rurais (Alarcão 1998), não será de todo improvável a hipótese de o núcleo habitado inicial da Lage do Ouro ter sido um casal ou uma pequena granja que foi prosperando ao longo dos tempos. A essa prosperidade terão correspondido ampliações nos edifícios e construções novas, e no séc. III teria adquirido as características de uma villa. No entanto, apesar dos mosaicos aqui 
encontrados, nunca teria atingido a dimensão das grandes villae do Alentejo como Torre de Palma, Pisões ou S. Cucufate ${ }^{3}$.

Entre os materiais exumados na necrópole, exceptuando alguns objectos de adorno e uma representação zoomórfica, em bronze, que serve de pega a um possível raspador de peles, não há qualquer outra peça de excepção pela sua beleza artística ou raridade. As cerâmicas comuns, muito semelhantes nos fabricos às das necrópoles de Elvas, seriam produzidas na região; as cerâmicas finas, embora de importação, são peças vulgares que poderiam ser adquiridas nos mercados da capital da civitas ou do Vicus Camalocensis, ali tão perto.

Os metais são essencialmente ferramentas agrícolas, que poderiam ter sido produzidos na própria villa se o indivíduo enterrado na sepultura L 38.5 fosse ferreiro, como o espólio o parece indicar.

Sintetizando, parece poder-se traçar um modelo de um casal ou granja que vai prosperando até que no séc. III se torna numa villa modesta; a partir daí, os seus habitantes, de origem indígena pelas epígrafes que os antepassados mandaram lavrar (IRCP 624 e 628), já se podiam dar ao luxo de possuir algumas jóias, adquirir cerâmicas de melhor qualidade e monumentalizar os seus túmulos. No entanto, o aprovisionamento é feito essencialmente na região.

As lucernas não contradizem este modelo. Não existem aqui as marcas de difusão supra-regional como a C. Oppius Restitutus da lucerna de encontrada na Torre das Arcas (Alarcão/Ponte 1976b: 83, n. $\left.{ }^{\circ} 19\right)$, nem as produções anónimas mas de características nitidamente norte-africanas como algumas de Balsa (Nolen 1994) ou Conimbriga (Alarcão/Ponte 1976b; Caetano 2001); pelo contrário, parecem ser todas de produção regional.

Desconhecendo-se a localização dos centros produtores, torna-se difícil perceber como é que estas peças entravam nas redes comerciais regionais e como se organizava a produção dentro nas olarias; a falta de paralelos para a maior parte destas lucernas também não ajuda a resolver estas questões.

A olaria de maior envergadura será a que fabricou as lucernas n. ${ }^{\text {os }} 2$ e 4, marcadas GES. Situar-se-ia em Mérida (Balil 1966: 122),

${ }^{3}$ Os fragmentos de mosaico na posse do Sr. João da Purificação, em Aldeia da Mata, apenas têm um simples padrão geométrico a preto e branco; nas construções actuais existentes no sítio da Lage do Ouro não foi notado o reaproveitamento de qualquer elemento arquitectónico de relevo. 
onde se fabricavam lucernas com outras marcas (Rodríguez Martín 1996), e o seu aparecimento em todo o Sul da Lusitânia leva a incluí-la no segundo modelo de difusão proposto por Harris, as lucernas de difusão provincial (1980: 129-130).

Considerando os 117 fragmentos encontrados junto à Praça de Touros desta cidade, nos quais "en el solero se repite la marca GES" e que esta "no es nueva en el Museo" (Alvarez Sáez de Buruaga 1955-1957: 209), poderia pensar-se que, seguindo as categorias de Peacock, funcionaria como uma olaria individual, familiar, ou mais provavelmente como uma manufactura, um grupo de artesãos com segmentação de tarefas e trabalho individualizado (Peacock 1982: 8-11).

Das restantes pouco se poderá dizer; terão sido fabricadas em pequenas olarias, com uma difusão local no sentido que lhe dá Harris, dentro do território da cidade (Harris 1980: 129). As palmas das n. ${ }^{\text {os }} 3$ e 6 tanto poderão ser marcas como ter intuitos decorativos; além disso o seu desenho é diferente e as pastas também o são, pelo que não parecem produto da mesma oficina. Para as lucernas n. ${ }^{\text {os }} 5,7,8$ e 9 somente a descoberta ou publicação de exemplares iguais poderá ajudar a enquadrá-las na produção licnológica regional.

Sobre este conjunto de lucernas da Lage do Ouro há ainda outros aspectos a salientar. Um primeiro é o tecnológico; houve pouco cuidado no fabrico, como se verifica pela utilização de valvas de modelos diferentes mas, ao mesmo tempo, sente-se o desejo de fazer peças agradáveis à vista, avivando as figuras ou acrescentando outros elementos decorativos após a moldagem.

Além disso, as características das lucernas indica que foram moldadas em moldes fabricados a partir de outras lucernas. É necessário acentuar que a cópia por remoldagem era frequente, havendo olarias que fabricavam exclusivamente cópias; são os casos de Montans, onde com as mesmas pastas e engobes das sigillatas aí fabricadas houve uma produção secundária de lucernas, cópias dos modelos mais em voga (Bergès 1989), ou de uma pequena olaria familiar existente na via di Nocera, em Pompeia, que fazia remoldagens sobre as lucernas à venda nos mercados da cidade (Cerulli Irelli 1977).

Um segundo aspecto tem a ver com a cronologia. Até onde serão válidas as datações propostas pelas diversas tipologias? Há vários exemplos conhecidos de lucernas de uma determinada época encontradas em sepulturas mais tardias (Bernal Casasola 1995: 385-188). 
Noutros casos, determinados tipos continuam a ser fabricadas nalgumas regiões, mesmo quando já não o são nas de origem.

Veja-se o caso das lucernas de volutas com vários bicos e asas plásticas (Bailey D). Existindo em Haltern num período datado entre 11 e 9 a.C., terão chegado ao quadrante norte-ocidental da Península Ibérica, somente no segundo quartel do séc. I d.C. No Norte de África a sua produção terá continuado durante toda a época flávia, quando é tradicionalmente aceite que terminou no início daquela dinastia (Caetano 2001: 49).

Nestas produções regionais o problema ainda se complica mais, sobretudo quando se trata de cópias modificadas, fugindo às formas clássicas. Será mais razoável, embora sempre tendo em conta as datações tradicionais, começar a construção de cronologias regionais, através da contextualização arqueológica das peças ou recorrendo aos paralelos exactos encontrados na mesma região.

Para este conjunto da Lage do Ouro isto só foi possível para a n. ${ }^{\circ}$; ; as restantes lucernas foram encontradas em sepulturas cujo espólio era constituído por cerâmica comum ou outros materiais com cronologia muito ampla. A falta de paralelos bem contextualizados também dificultou uma definição cronológica mais precisa para as peças.

\section{Catálogo}

O inventário desta necrópole foi elaborado considerando cada túmulo individualmente. L 38.3.10 indica o quadrado L 38, a sepultura n. ${ }^{\circ} 3$ desse quadrado, e a peça $n .^{\circ} 10$ da sepultura, listada pela ordem em que foi encontrada. C, L e A indicam respectivamente comprimento, largura e altura; para as cores foi utilizado o Código de Cores Cailleux. Quando possível classifica-se a orla segundo a sistematização elaborada por Loeschcke.

\section{N. ${ }^{\circ}: 1$ N. ${ }^{\circ}$ Inventário: I 37.7:1}

Lucerna Bailey P-I com orla Loeschcke IIIb. Orla direita na parte superior, separada do disco por uma moldura larga e direita. Disco bastante côncavo, sem decoração. Sem asa. Base alteada marcada por um sulco. Pasta dura e compacta, com finos grãos de quartzo, de cor bege escura (N53); engobe acastanhado, mais escurecido na zona do bico (N49), pouco espesso e aderente. C: $76 \mathrm{~mm}, \mathrm{D}: 62 \mathrm{~mm}, \mathrm{~A}: 24 \mathrm{~mm}$ 


\section{N. : 2 N. ${ }^{\circ}$ Inventário: J 33.1:1}

Lucerna Bailey P-I com orla Loeschcke VIIb. Bico redondo, separado do corpo da lucerna por dois traços paralelos incisos, entre os quais há uma decoração espinhada, também incisa. Na sua parte inferior, uma palma esgrafitada. Orla arredondada, separada do disco por um sulco; no disco uma figura de relevos pouco nítidos, mas que poderá ser Minerva, virada à direita, segurando na mão direita uma lança e na esquerda um escudo. Orifício de alimentação no lado direito do disco, à esquerda da decoração. Base marcada com uma canelura, tendo no centro a marca esgrafitada GES sobre palma. Pasta medianamente dura, bege rosada (L70); vestígios de engobe castanho escuro. C: $96 \mathrm{~mm}, \mathrm{D}: 73 \mathrm{~mm}, \mathrm{~A}$ : $34 \mathrm{~mm}$.

\section{N. ${ }^{\circ}: 3$ N.․ Inventário: L 38.3:10}

Lucerna Bailey O com orla Loeschcke IVa. Orla decorada com estrias, separada do disco por uma moldura. O disco ostenta a figura de Hélios radiado, segurando um chicote. Base rodeada por uma moldura pouco alteada, marcada com uma palma. Asa Ponsich 7, decorada com uma palma. Pasta dura e homogénea, com mica e calcite, bege acastanhada (M47); vestígios de engobe acastanhado. C: $128 \mathrm{~mm}$, D: $85 \mathrm{~mm}$, A: $38 \mathrm{~mm}$

\section{N. ${ }^{\circ}: 4$ N. ${ }^{\circ}$ Inventário: L 39.3:4}

Lucerna Bailey Q-IV. Orla direita, separada do disco por duas molduras, sendo a exterior mais larga. Disco com Vitória, de frente sobre um globo, de braço direito levantado segurando uma coroa e tendo na mão esquerda a palma; as pontas das asas, da palma, a coroa e parte do globo sobrepõem-se às molduras que separam o disco da orla. Asa de forma semelhante à Ponsich 7, mas estendendo-se pelo reservatório até à base, e decorada com uma palma. Base envolvida por duas molduras largas, pouco salientes, com a marca incisa GES. Pasta dura e compacta, com pontos de quartzo, mica e calcite de reduzidas dimensões, de cor alaranjada, variando entre o N39 e o N45; vestígios de engobe avermelhado. C: $115 \mathrm{~mm}, \mathrm{D}: 81 \mathrm{~mm}, \mathrm{~A}: 39 \mathrm{~mm}$.

\section{N. ${ }^{\circ}: 5$ N. ${ }^{\circ}$ Inventário: G 37.3:3}

Lucerna Bailey Q-VIII com orla Loeschcke VIIb. Orla estreita decorada com uma fiada de pérolas grandes, separada do disco por um sulco. O disco é bastante côncavo e tem nove palmas dispostas radialmente a partir de uma moldura decorada com incisões; no centro desta moldura está o orifício de alimentação, levemente descentrado para a direita. Asa Ponsich 8, decorada com uma palma incisa. Base definida 
por duas molduras concêntricas, a exterior mais larga que a interior, e que tem no centro um círculo impresso. Decoração avivada a estilete. Pasta medianamente dura, com finos grãos de quartzo, mica e nódulos de barro, bege escura (N47); engobe espesso e aderente, castanho escuro (S47). C: $110 \mathrm{~mm}, \mathrm{D}: 74 \mathrm{~mm}, \mathrm{~A}: 29 \mathrm{~mm}$

\section{N. ${ }^{\circ}: 6$ N. ${ }^{\circ}$ Inventário: G 37.2:36}

Lucerna Bailey Q-X com orla Loeschcke VIIib. Orla larga decorada com cinco fiadas concêntricas de pérolas, separada do disco por uma moldura larga. O disco é bastante côncavo, com o orifício de alimentação no eixo da lucerna, mas um pouco descentrado para cima. Asa Ponsich 8, decorada com duas incisões longitudinais que terminam numa palma incisa; base definida por uma moldura pouco relevada, marcada com uma palma, orientada no sentido do eixo da lucerna. Pasta medianamente dura, com alguns quartzos de médias dimensões e com orifícios resultantes do desaparecimento de matéria orgânica; cor bege (K70); vestígios de engobe acastanhado (P79). C: $116 \mathrm{~mm}, \mathrm{D}: 80 \mathrm{~mm}$, A: $31 \mathrm{~mm}$.

\section{N. ${ }^{\circ} 7 \quad$ N. ${ }^{\circ}$ Inventário: I 39.4:33}

Lucerna Bailey N. Orla lisa e descaída, com o que parece ser uma protuberância, típica destas lucernas, mas com o relevo muito sumido; disco pequeno e pouco profundo separado da orla por uma moldura alta, que também limita o canal que o liga ao bico, envolvendo este; orifício de alimentação centrado e rodeado por uma moldura semelhante. Asa decorada com dois sulcos longitudinais, entre os quais está uma palma incisa. Base definida por dois círculos concêntricos. Pasta medianamente dura, homogénea, com micas, calcites e quartzos, estes de dimensões médias; apresentam vacuolos onde haveria matéria orgânica; cor laranja acastanhada (N45); alguns vestígios de engobe acastanhado (R39). C: 116 mm, D: 63 mm, A: $32 \mathrm{~mm}$.

\section{N. ${ }^{\circ}: 8$ N. ${ }^{\circ}$ Inventário: L 38.4:20}

Lucerna Bailey N. Orla larga e descaída, decorada por um cordão de palmas em ziguezague, com as incisões retocadas após moldagem. O disco é pequeno e profundo, e está decorado com um busto virado à esquerda, e cujo braço direito, dobrado atrás da cabeça, empunha o que parece ser um bastão. A moldura que separa a orla do disco forma um canal curto, ligando-o ao bico, que também rodeia, e está decorada com as mesmas incisões espinhadas do cordão da orla. Asa Ponsich 8, decorada longitudinalmente com três sulcos. Base definida por duas incisões concêntricas, formando uma moldura, e marcada com três traços rectos, 
que se cruzam no centro, dividindo-a em seis partes. No centro de cada uma destas divisões há um ponto impresso. Pasta medianamente dura, com mica, calcite e quartzo, variando entre o alaranjado claro e o escuro (N39 e P37); engobe pouco espesso e mal aderente, acastanhado (P35). C: $117 \mathrm{~mm}, \mathrm{D}: 77 \mathrm{~mm}, \mathrm{~A}: 34 \mathrm{~mm}$.

\section{N. ${ }^{\circ} 9$ N. ${ }^{\circ}$ Inventário: L 28.4:2}

Lucerna Bailey $\mathrm{R}$ (?). Lucerna de bico redondo, muito grosseira, com os relevos muito sumidos. Orla larga e descaída, decorada com o que parecem ser estrias radiadas; no disco notam-se também algumas estrias que poderão ser de uma concha. Apenas existe o arranque da asas, junto ao reservatório. Pasta: medianamente dura, muito grosseira, com quartzos, micas e calcites de grandes dimensões, de cor alaranjada (variando entre o M45 e o R39); engobe vestígios de engobe acastanhado escuro (R35). C: $95 \mathrm{~mm}, \mathrm{D}: 71 \mathrm{~mm}, \mathrm{~A}: 39 \mathrm{~mm}$.

\section{BIBLIOGRAFIA}

Alarcão, A. M.; Alarcão, J. (1966) - O espólio da necrópole luso-romana de Valdoca (Aljustrel). Conimbriga. Coimbra. 5. p. 7-104.

Alarcão, A. M.; Ponte, S. (1976a) - Les lampes. In Alarcão, J.; Etienne, R. (dir.). Fouilles de Conimbriga. VI. Céramiques diverses et verres. Paris: Diffusion E. de Boccard. p. 93-114.

Alarcão, A. M.; Ponte, S. (1976b) - Lucernas romanas do Paço Ducal de Vila Viçosa. Conimbriga. Coimbra. 15. p. 73-90.

Alarcão, J. (1974) - A necrópole do Monte do Farrobo (Aljustrel). Conimbriga. Coimbra. 13. p. 5-32.

AlArCão, J. de (1998) - A paisagem rural romana e alto-medieval em Portugal. Conimbriga. Coimbra. 37. p. 89-119.

Almeida, J. A. F. (1951) - Três lucernas do museu de Santiago do Cacém. O Arqueólogo Português. Lisboa. S. 2. 1. p. 271-287.

AlmeidA, J. A. F. (1953) - Introdução ao estudo das lucernas romanas em Portugal. O Arqueólogo Português. Lisboa. S. 2. 2. p. 5-208.

Alvarez Saenz de Buruaga, J. (1955-1957) - Museo Arqueológico de Mérida (Badajoz). Nuevas adquisiciones. Memorias de los Museos Arqueologicos Provinciales. Madrid. 16-18. p. 207-211.

BAILEY, D. M. (1980) - A catalogue of the lamps in the British Museum. II. Roman lamps made in Italy. Londres: The British Museum Trusts.

BALIL, A. (1966) - Materiales para un índice de marcas de ceramista en lucernas de fabricación hispánica. Pyrenae. Barcelona 2. p. 117-123.

BelCHIOR, C. (1969) - Lucernas romanas de Conimbriga. Coimbra: Museu Monográfico de Conimbriga. 
Bergès, G. (1989) - Lampes de Montans. Paris: La Maison des Sciences de l'Homme (Documents d'Archéologie Française, 21).

Bernal CASASOla, D. (1995) - Economia lychnológica hispana: valoración actual del proceso de manufactura de lucernas en época romana y su inserción en el contexto Mediterráneo. Trabalhos de Antropologia e Etnologia. Porto. 35(1). p. 369-396 (I Congresso de Arqueologia Peninsular. Actas, vol. 5).

Bonnet, J. (1988) - Lampes céramiques signées. Paris: La Maison des Sciences de l'Homme (Documents d'Archéologie Française, 13).

Cabral, M. E. F. (1974-1977) - Lucernas romanas de Alcácer do Sal. O Arqueólogo Português. Lisboa. S. 3. 7/9. p. 347-354.

CABral, M. E. F. C. N. (1973) - Cinco lucernas inéditas da Barrosinha. in Actas das II Jornadas Arqueológicas. Lisboa: Associação dos Arqueólogos Portugueses. Vol. II. p. 175-184.

CABraL, M. E. F. C. N. (1978) - Marcas de oleiro em lucernas romanas de Balsa, Torre d'Ares. in Actas das III Jornadas Arqueológicas. Lisboa: Associação dos Arqueólogos Portugueses. Vol. I. p. 237-248.

CAetano, J. C. (2002) - Necrópoles e ritos funerários no Ocidente da Lusitânia romana. in VAQUERIZO, D. (Ed.) - Espacios y usos funerarios en el Occidente Romano. Córdoba: Seminario de Arqueología/Universidad de Córdoba. Vol. I. p. 313-334.

CAetano, J. C. M. (2001) - Lucernas romanas de Conimbriga. Escavações de 1963-1970. Coimbra: Faculdade de Letras (Dissertação de Mestrado em Arqueologia, policopiado).

CailleuX, A. (s/d) - Notice sur le Code des couleurs des sols. Paris: Boubée.

Cerulli Irelli, G. (1977) - Oficina di lucerne fittili a Pompei, $L$ ' instrumentum domesticum di Ercolano e Pompei nella prima etá imperiale. Roma: "L'Erma" di Bretscneider (Quaderni di Cultura Materiale, 1). p. 53-72.

Costa, M. E. F. (1973) - Lucernas romanas de Tróia de Setúbal (Museu Nacional de Arqueologia). Lisboa: Faculdade de Letras (Dissertação de licenciatura em História, policopiado).

Deneauve, J. (1969) - Lampes de Carthage. Paris: Éditions du C.N.R.S..

EnCARnaÇão, J. d' (1984) - Inscrições romanas do conventus Pacensis. Coimbra: Faculdade de Letras/Instituto de Arqueologia.

Fabião et. al. (1988) = Fabião, C.; Guerra, A.; Laço, T.; Melro, S.; Ramos, A. C. (1998) - Necrópole romana do Monte Novo do Castelinho (Almodôvar). Revista Portuguesa de Arqueologia. 1(1). p. 199-220.

Fitch, C. R.; Goldman, N. W. (1994) - Cosa: The Lamps. Ann Arbour: American Academy in Rome (Memoirs of the American Academy in Rome, 39).

FRADE, H. (1998) - Terra sigillata hispânica tardia da necrópole romana da Lage do Ouro (Crato). Coimbra: Faculdade de Letras (Trabalho apresentado ao Seminário de Cerâmica Romana do Mestrado em Arqueologia, policopiado).

Frade, H.; Caetano, J. C. (1985) - A necrópole romana da Lage do Ouro. Primeiros

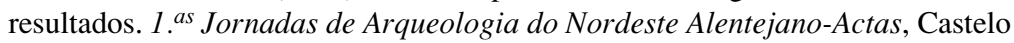
de Vide. p. 133-143. 
Frade, H.; CAetano, J. C. (1991) - Necrópole romana da Lage do Ouro - Novos elementos. Conimbriga. Coimbra. 30. 1991. p. 39-57.

Frade, H.; CAetano, J. C. (1993) - Ritos funerários romanos no Nordeste Alentejano. 2. ${ }^{\circ}$ Congresso Peninsular de História Antiga. Actas (Coimbra, 18-20 de Outubro de 1990). Coimbra p. 847-872.

HARRIS, W. V. (1980) - Roman terracotta lamps: The organization of an industry. The Journal of Roman Studies. London. 70. p. 126-145.

IRCP = ENCARNAÇão 1984.

Lopez Rodriguez, J. R. (1981), "La coleccion de lucernas de la Casa de la Condesa de Lebrija", Boletín del Seminario de Estudios de Arte y Arqueologia, 47, p. 95$-141$.

LuZón Nogué, J. M. (1967) - Lucernas mineras de Riotinto. Archivo Español de Arqueologia. Madrid. 40. p. 138-150.

Morillo Cerdan, A. (1999) - Lucernas romanas de la región septentrional de la Península Ibérica. Montagnac: Éditions Monique Mergoil (Monographies Instrumentum; 8).

Nolen, J. U. S. (1985) - Cerâmica comum de necrópoles do Alto Alentejo. Lisboa: Fundação da Casa de Bragança.

Nolen, J. U. S. (1994) - Cerâmica e Vidros de Torre de Ares. Balsa. Lisboa: Instituto Português de Museus.

NoLEN, J. U. S. (1995-1997) - Acerca da cronologia da cerâmica comum das necrópoles do Alto Alentejo: novos elementos. O Arqueólogo Português. Lisboa. S. 4. $13 / 15$, p. $347-392$

PeAcock, D.P.S. (1982) - Pottery in the Roman world. An ethnoarchaelogical approach. Londres: Longman.

RodríGuez Martín, F. G. (1996) - Materiales de un alfar emeritense: Paredes finas, lucernas, sigillatas y terracotas. Merida: Museo Nacional de Arte Romano (Cuadernos Emeritenses; 11).

SEPúlVEDA, E.; Sousa, V. R. C. (2000) - Lucernas romanas. Catálogo. Torres Vedras: Câmara Municipal de Torres Vedras/Museu Municipal Leonel Trindade.

Simões, M. H. (1985) - Vidros romanos do Museu do Crato. 1. as Jornadas de Arqueologia do Nordeste Alentejano-Actas. Castelo de Vide. p. 123-125

Viegas, J. R., Nolen, J. U. SMit, Dias, M. L. F. (1981) - A necrópole de Santo André. Conimbriga. Coimbra. 20. p. 5-180. 

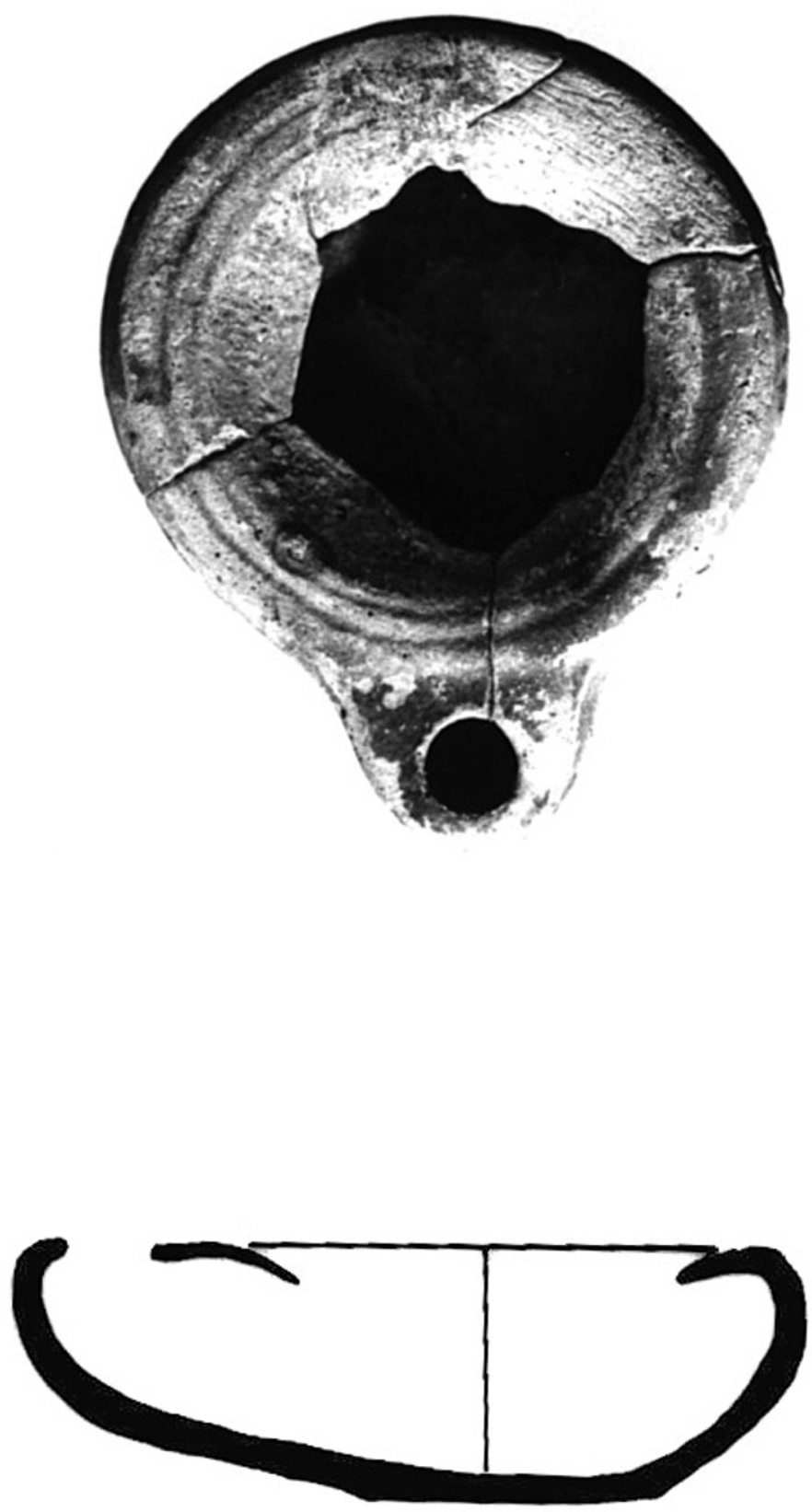

EsT. I 

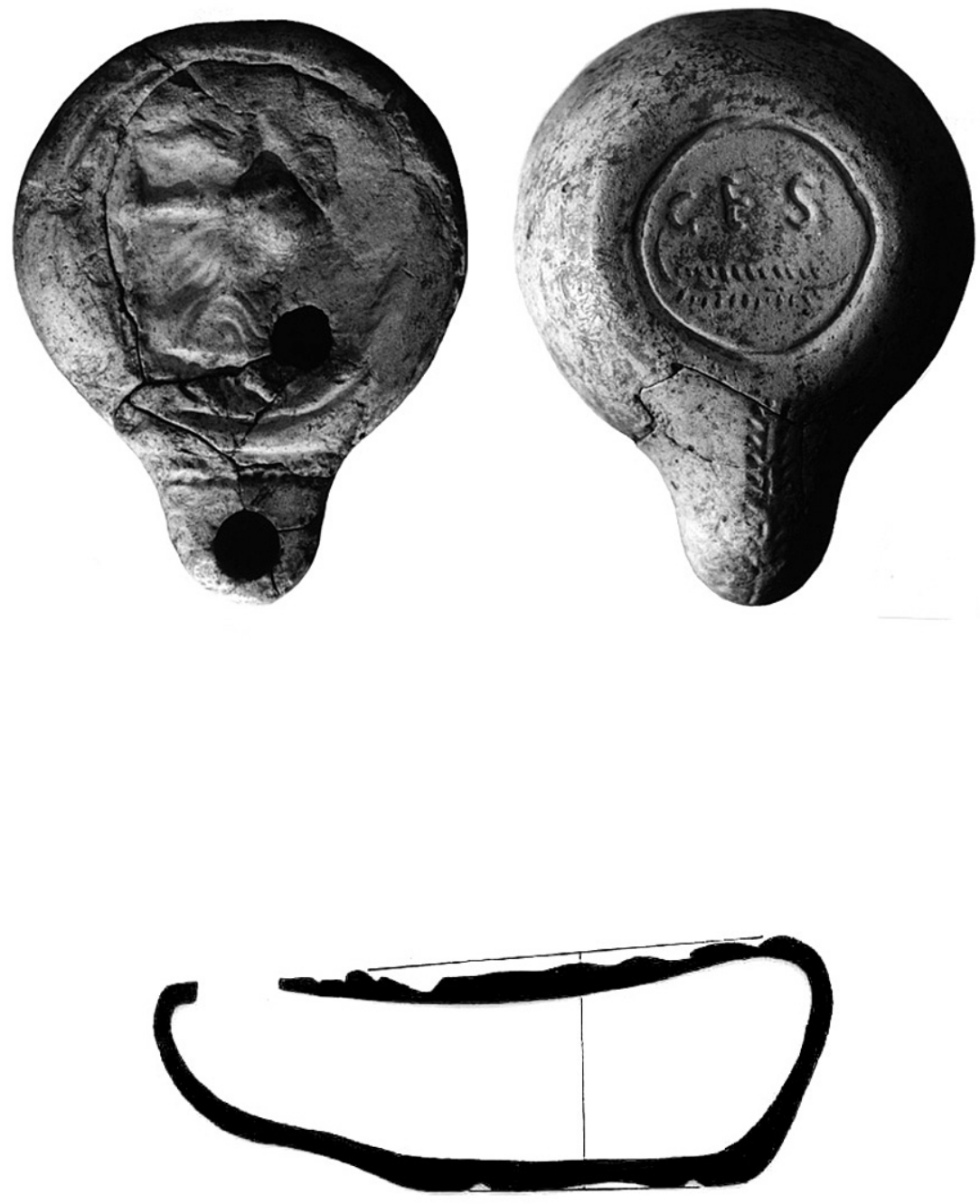

EST. II 

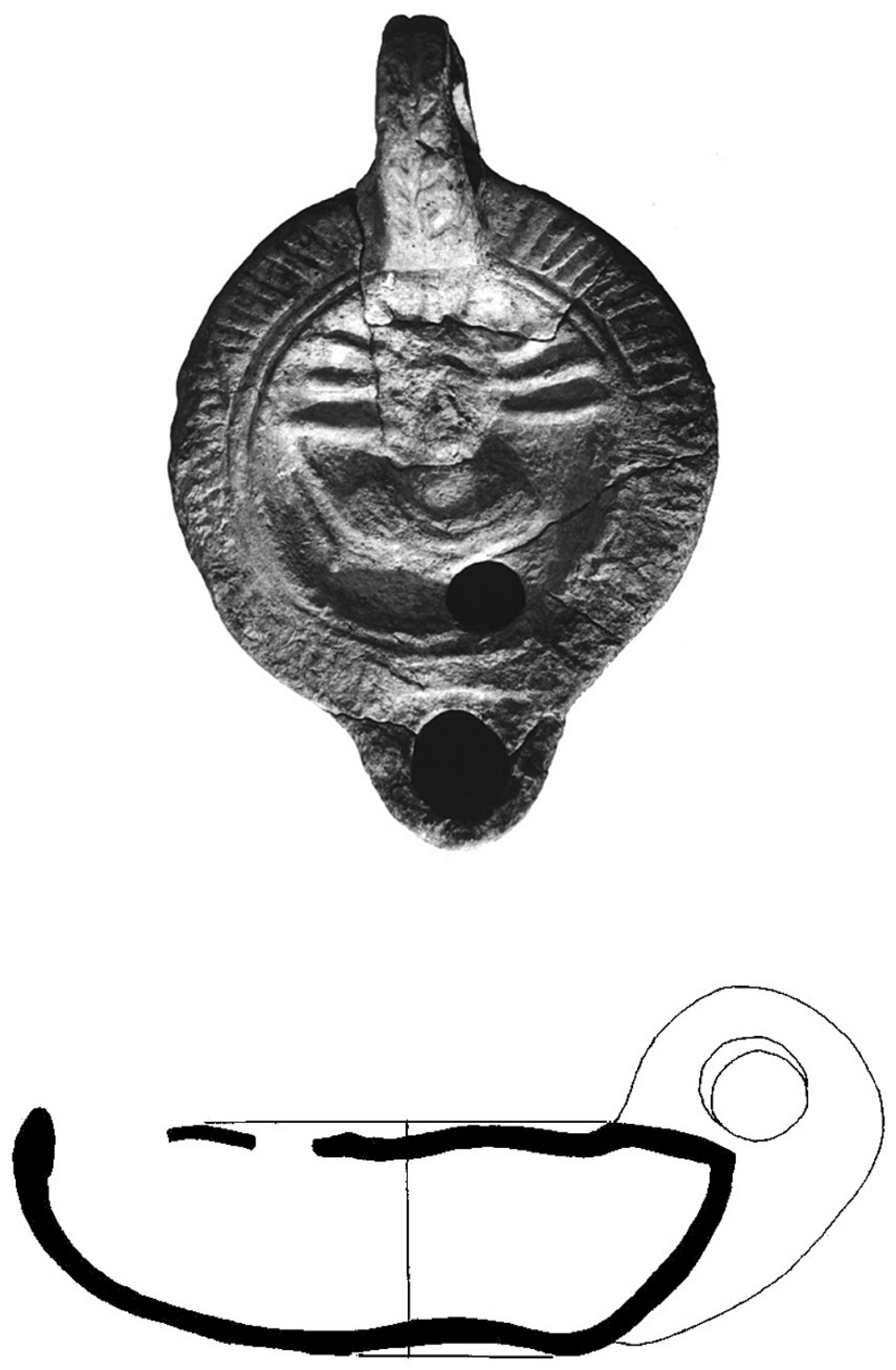

EsT. III 

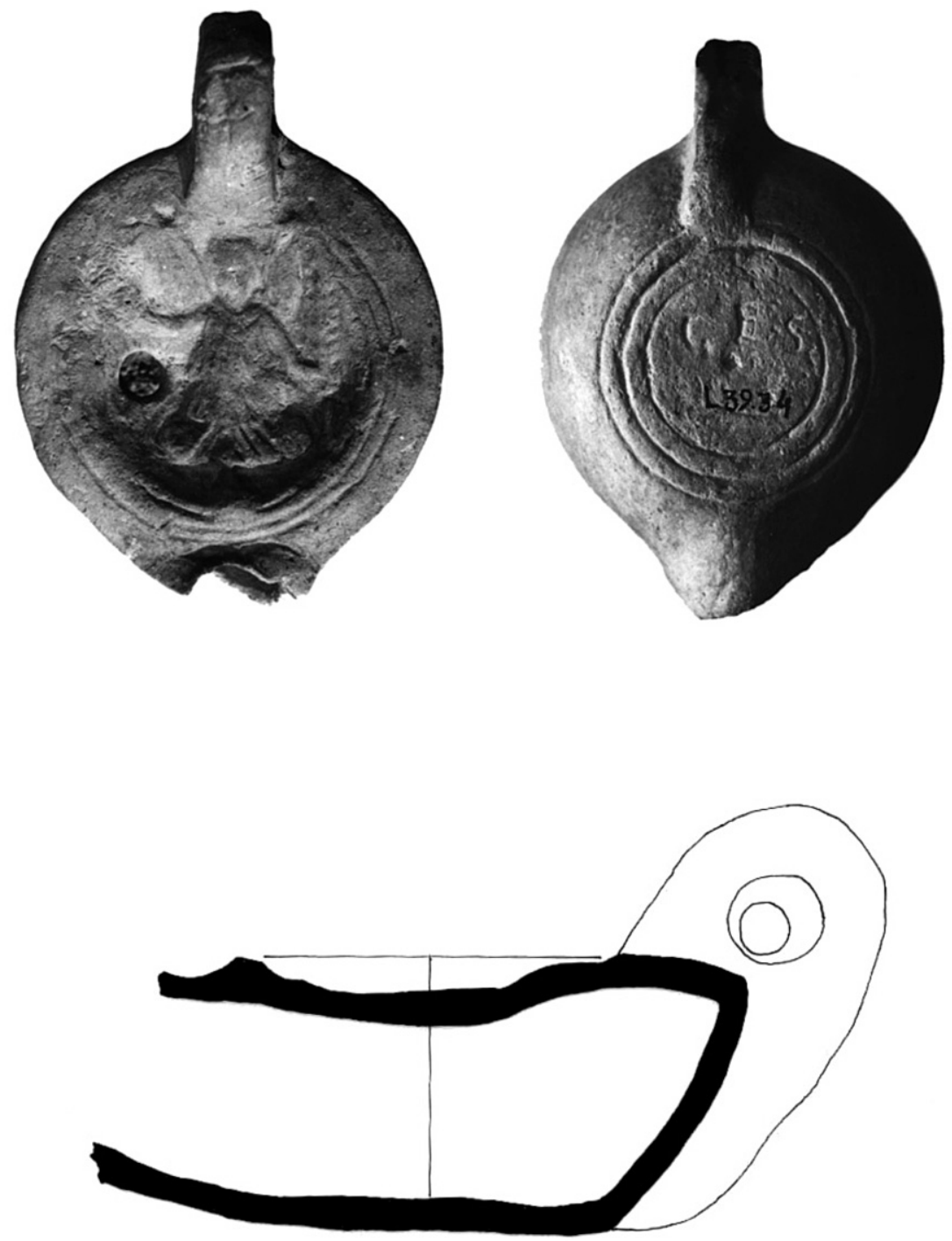

EsT. IV 

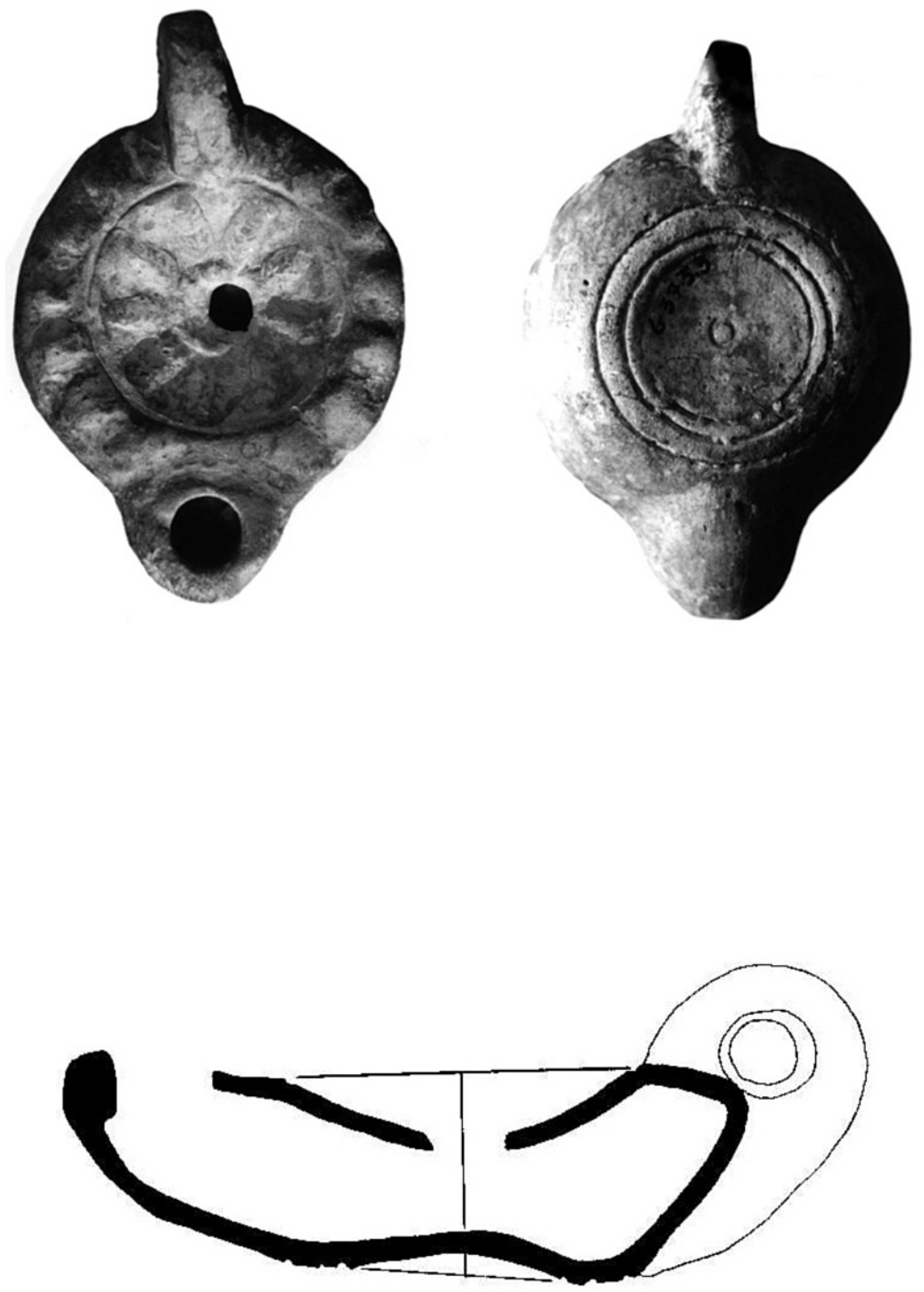

EsT. V 

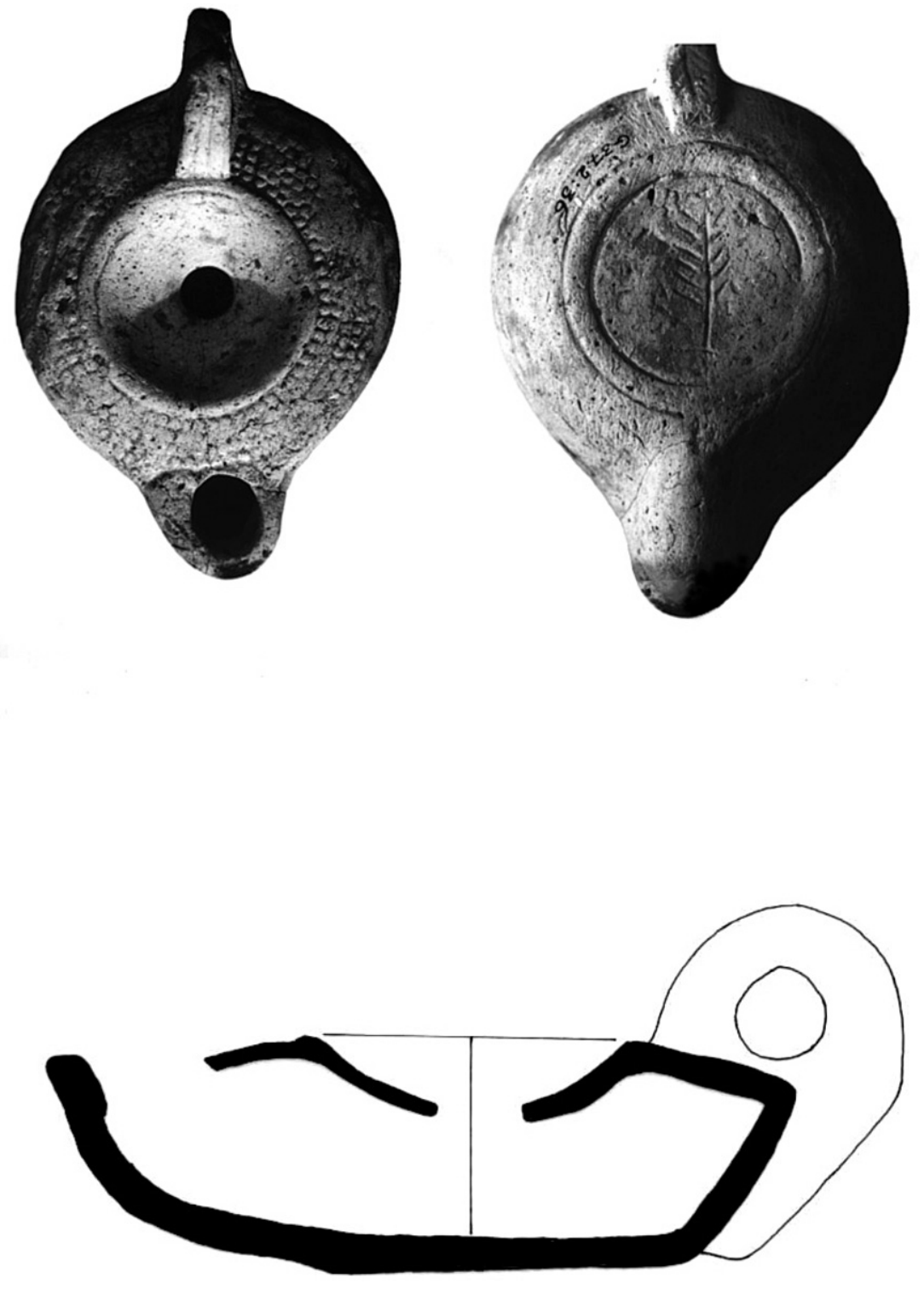

EsT. VI 

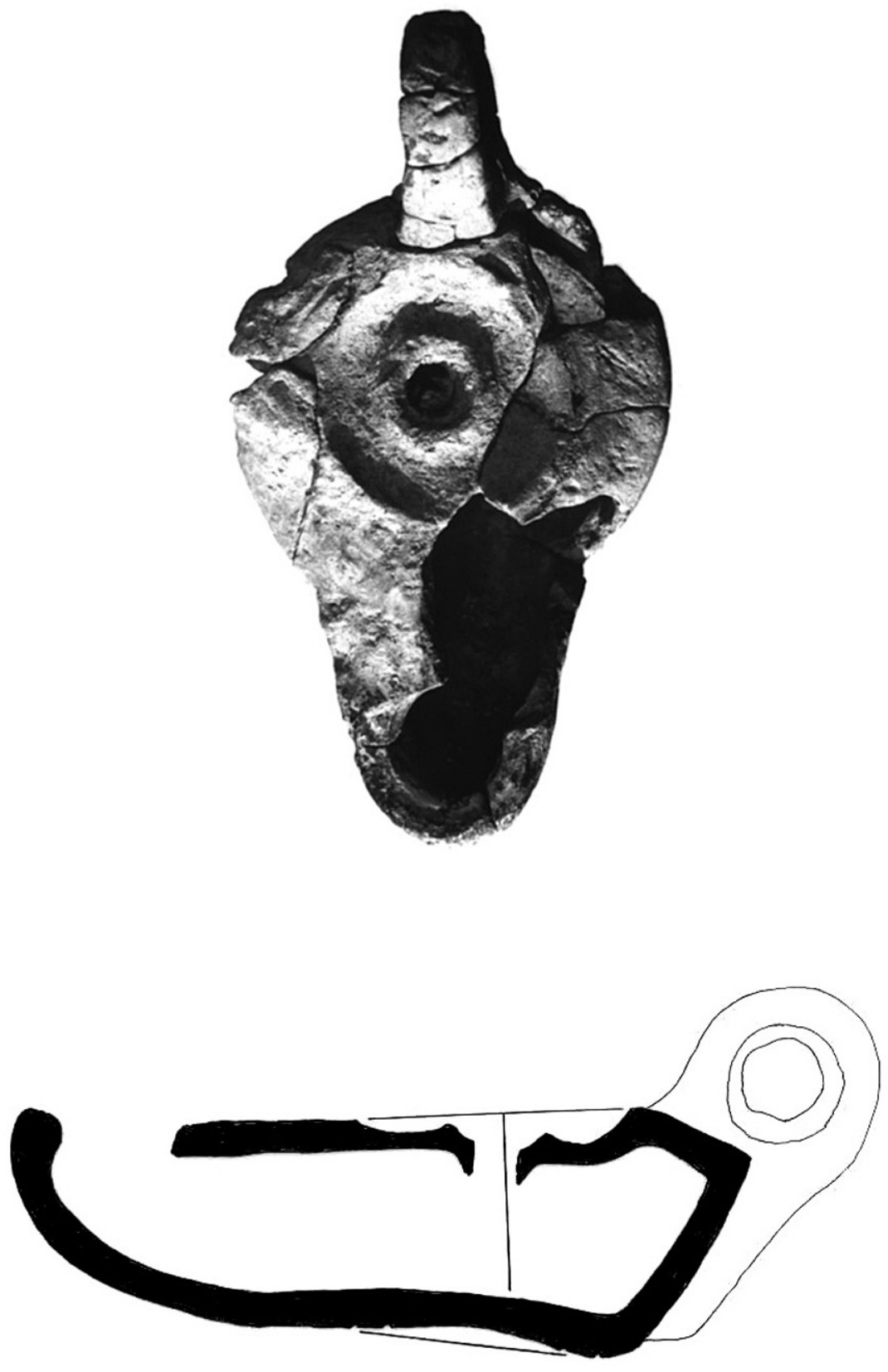

EsT. VII 


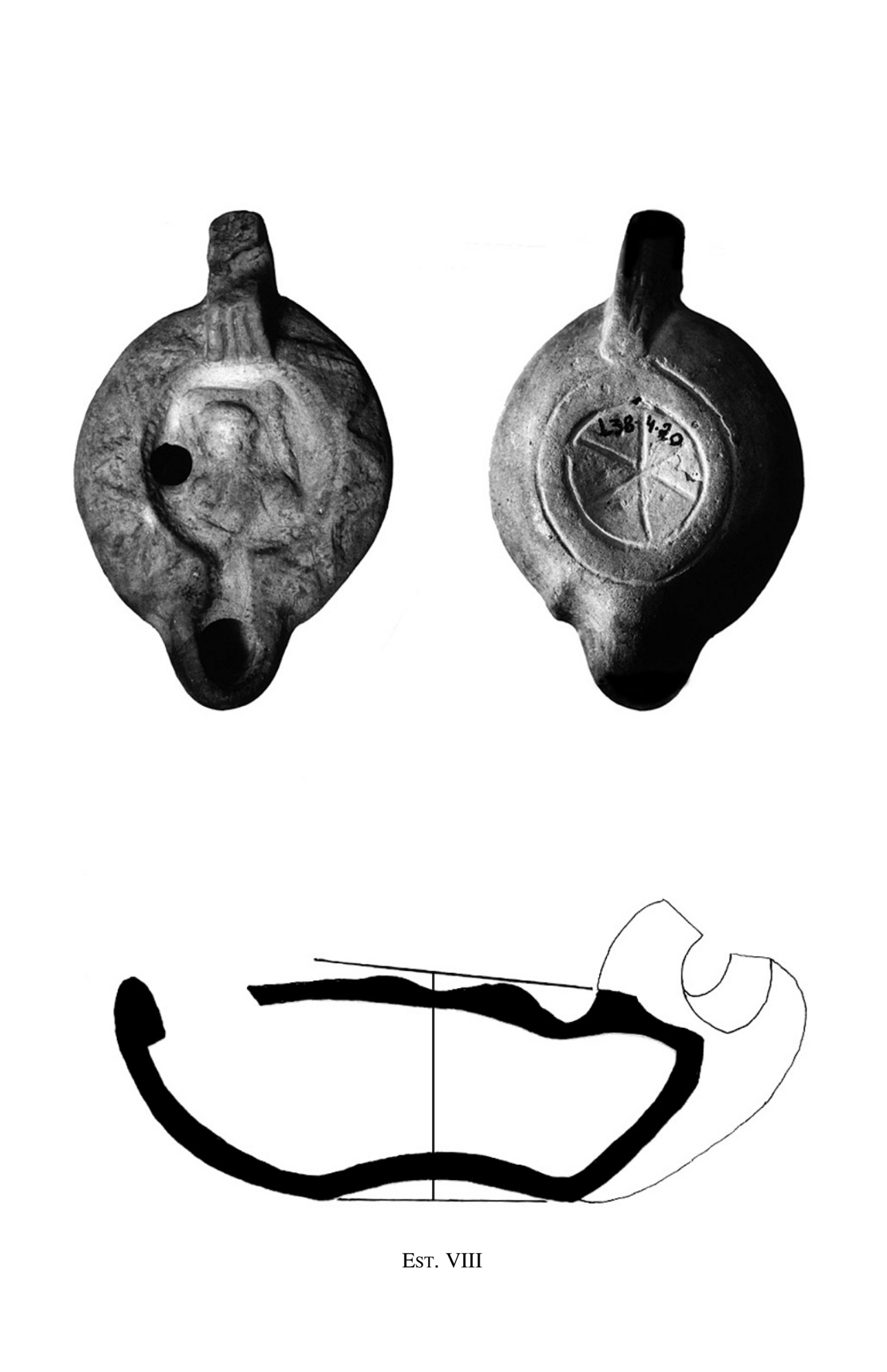



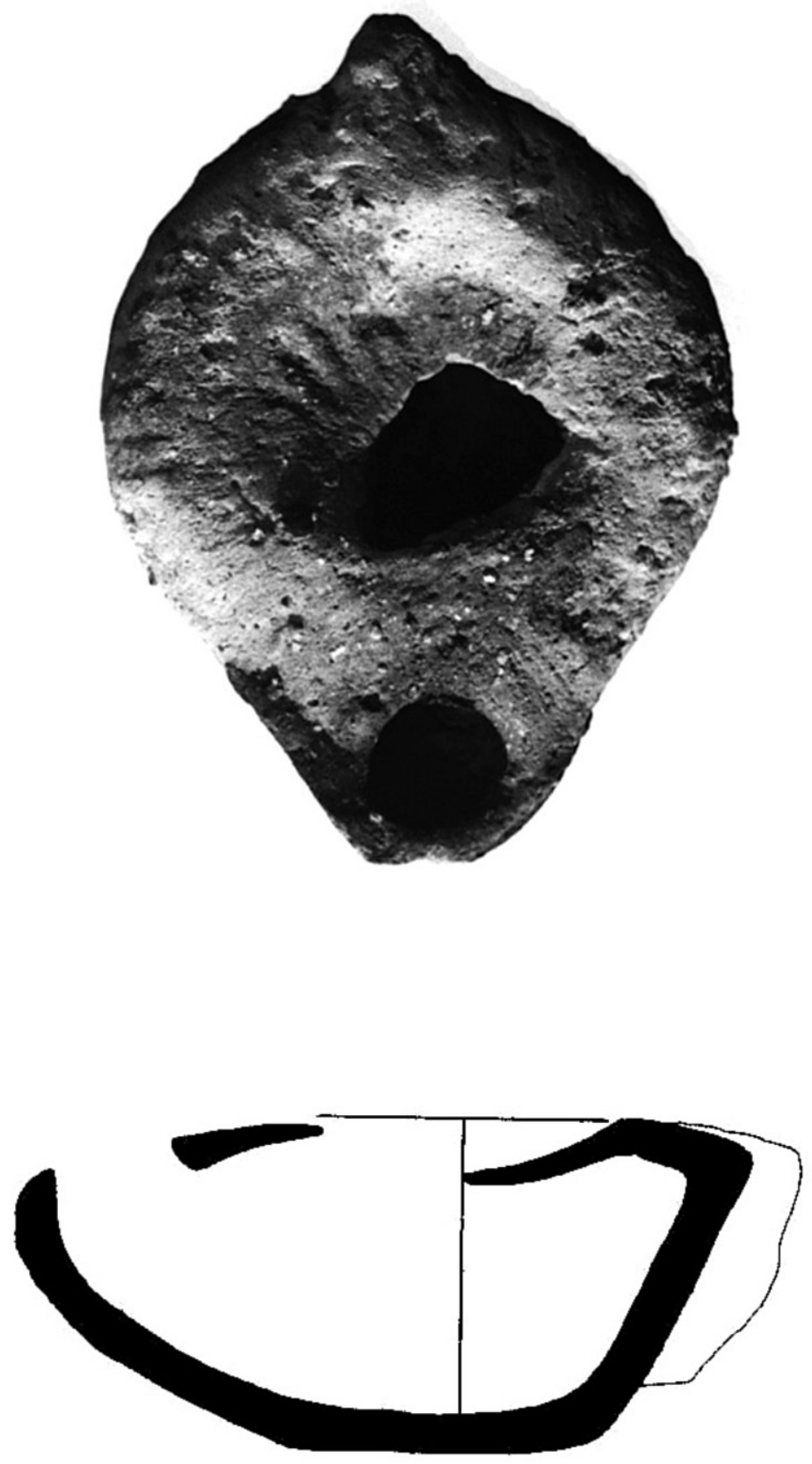

Est. IX 